\title{
ECONOMIC SUCCESS STORY SOUTH KOREAN WAY
}

\author{
Alexander Mechitov, University of Montevallo, Montevallo, Alabama, U.S.A. \\ Helen Moshkovich, University of Montevallo, Montevallo, Alabama, U.S.A. \\ Levi Springer, University of Montevallo, Montevallo, Alabama, U.S.A.
}

dx.doi.org/10.18374/JIFE-19-3.1

\begin{abstract}
The paper studies economic success story of South Korea. Authors analyze the history of economic progress in South Korea and its main underlying factors, including political and cultural environment, business climate, industrial policy, demographics, etc. The paper specifically analyzes the role of state in identifying national priorities and promoting economic reforms. Special attention is paid to South Korea's educational system which is considered today to be one of the best in the world. The study concludes with discussing the country's road to success and potential weaknesses (archaic business structure, aging population, increasing competition from neighboring Asian countries), which might represent interest to many who study emerging markets and try to analyze and capitalize on the main ingredients of South Korean success story.
\end{abstract}

Keywords: South Korea, economic reforms, economic transformation, education reforms 